\title{
Influence of Education, Motivation and Discipline on the Performance of Military Personnel in the Naval Education Service
}

\author{
Rini Ariyani \\ \{riniariyani252@gmail.com\} \\ Universitas Mercu Buana, Jakarta, Indonesia
}

\begin{abstract}
This study aims to examine and analyze the effect of education, motivation discipline of military personnel in Naval Education Services. This research data is primary data, in the form of respondent's responses to questionnaires distributed. The sampling method used is random sampling data were analyzed using multiple linear regression analysis method. The results showed that education, motivation and discipline had a significant effect on the performance of military personnel naval education service. Partially education has a positive and significant effect on the performance of military personnel with motivation which was also found to have a positive and significant effect on the performance of military personnel. Discipline also has a positive and significant effect on the performance of military personnel.
\end{abstract}

Keywords: Education personnel, Motivation personnel, Discipline personnel and Performance

\section{Introduction}

In realizing a reliable, strong and professional TNI, it is necessary to improve the quality of competence of its personnel. According to (Pfeffer, 1994) in Mangkunegara [1] "Machines don't make things, but people do" which means investment in technology only provides limited competitive advantage. Whereas investment in human resources is more valuable. Institutions or organizations in the field of human resources certainly want every time to have quality human resources in the sense of meeting the competency requirements to be utilized in realizing vision and achieving medium-term and short-term goals. In order to achieve the stated objectives of human resource management, human resources must be developed and updated so that all organizational functions can run in harmony. Human resource activities are the most central part of the human resource management process and are a series of successes in achieving organizational goals. The activity will run smoothly, if it utilizes management functions.

In the development of 4.0 era, it made space and time as without a partition, so that everything that was done became easy with the development of technology and information. Thus, economic growth occurs so rapidly and increased interaction between cultures that can result in increased problems that occur due to the impact of globalization [2][3]. The Navy's current organization is required to keep abreast of the times, so the organization must be able to analyze the factors that can influence the performance of personnel. In overcoming this 
matter, human resource is the most important thing that must be considered its development, because with the presence of good and professional human resources will be very helpful in maximizing performance in an organization.

Factors affecting employee performance are Education, Motivation and Discipline [4], [5], [6]. Education is a guideline in fostering careers. After they carry out education, they will get a promotion to a higher career level. In terms of job placement and promotion, the most influential factor is the education of the personnel. By having a higher career path, these personnel will be more motivated to be able to improve their personal discipline. From some of these statements it can be concluded that the occurrence of poor employee performance is a result of a weak increase in the capacity of the apparatus' resources, namely through unplanned and programmed education and training programs [7], [8], [9], [10]. According to RI Law Number 2 of 1989 concerning the National Education System, what is meant by education is "A conscious effort to prepare students through guidance, teaching, and / or training activities for their role in the future. "

Education becomes an obstacle to the development of an organization within the Navy. With standards that have been adjusted to the needs of the organization, it is expected that problems related to this matter can be overcome. Education is a form of obligation and also an appreciation of the organization for Navy personnel, so it needs to be carefully planned by management so as not cause problems later on. Personnel's motivation can also be a powerful influence in developing the capabilities that personnel have to their abilities can be maximized. The discipline that has been applied has been adapted to the needs of the organization as a solid foundation pillar in maintaining or protecting the Navy personnel from misconduct.

The Indonesian Navy's organization requires the skills of each personnel to minimize the problems that are carried out at work while the Navy's personnel when working both at home and abroad who need to develop the personal quality of the personnel. Examples of problems experienced by Naval Education Work Units are when there is a demand for personnel to carry out overseas study assignments but is constrained in the English ability of personnel that is lacking so there is no or less interest in being able to carry out or fulfill the learning task, so the offer given finally given by another work unit. The data obtained by the level of education of Disdikal personnel who carry out education both in our country and abroad.

Table 1. The Military Personal

\begin{tabular}{lcccccc}
\hline \multicolumn{1}{l}{ Education } & Officer 45 & $\%$ & NCO 15 & \% & Private 10 & $\%$ \\
\hline $\begin{array}{l}\text { Senior High } \\
\text { School }\end{array}$ & 9 & $20 \%$ & 10 & $67 \%$ & 9 & $90 \%$ \\
$\begin{array}{l}\text { Diploma } \\
\text { Bachelor }\end{array}$ & 5 & $11 \%$ & - & - & - & \\
$\begin{array}{l}\text { Degree } \\
\text { Post Graduate }\end{array}$ & 10 & $22 \%$ & 5 & $33 \%$ & 1 & $10 \%$ \\
Doctoral & 17 & $38 \%$ & - & - & - & - \\
\hline
\end{tabular}

The total amount of The Military personnel totaled 70 people consisting of Officers, NCO and Private, but only $15 \%$ of the total amount who have capable in English. Based on the formulation of the goal problems in this study is to determine the effect of: Does 
Education affect skills and abilities after attending Education? Does motivation in completing work affect the performance better? Can discipline carried out by personnel improve the performance of personnel? Does having a good performance improve the quality standards of the Disdikal Working Unit?

\subsection{Education}

Even the development of human resources according to Reid [11] is the ability, skills and attitudes of personnel / members to be improved so that they are more effective and efficient in achieving program or organizational goals. According to Manullang [12] the goals of employee development are actually the same as the goals of employee training. Indeed, the objective of training or effective employee development goals is to obtain three things, they are: Increase knowledge, Add skills, Change attitude.

\subsubsection{Motivation}

According to Herzberg [13] in Sedarmayanti [14] developed Maslow's hierarchy of needs theory into two two-factor theories about motivation. These two factors are called motivation factors which are called satisfier or intrinsic motivation and maintenance factors which are called dissatisfier or extrinsic motivation. Satisfaction factors which are also called motivators which are factors that drive a person to achieve are sourced from within oneself (intrinsic condition) including: Achievement, Recognition of others, Responsibility, Opportunities for advancement, Job satisfaction itself (the work self), The possibility of career development (the responsibility of growth) [15], [16], [17].

\subsubsection{Discipline}

According to Singodimedjo (2000) [18] Factors that influence disciplines are: The size of the compensation. There is no exemplary leadership in the institution. There are no definite rules that can be used as a handle. Courage of the leader in taking action. The presence or absence of leadership of the leader. The presence or absence of attention to the personnel. Created habits that support the establishment of discipline [4], [19], [20].

\section{Research Method}

The source of this study's data consisted of primary data and secondary data. Primary data in this study were obtained through a questionnaire created by the author and distributed to all Military personnel of the Navy's Education Staff. Research model on the Influence of Education, Motivation and Discipline on Performance on the Unity of the Navy Education Office is conducted with as many as 70 respondents conducted by the author on the Research Model on the Effect of Education, Motivation and Discipline on Performance on the Unity of the Navy Education Office. Secondary data in this study were obtained through archives of the Navy's Office of Education which were not publicly published.

The flow of thought in this analysis is initiated by identifying the factors of Education, Motivation and Discipline. Indicators of other forms of education: Knowledge, Skills, behavior that is worth a struggle Indicators of Motivation include: Physiological Needs, Safety and Comfort Needs, Social Needs, Self-Esteem Needs, and Self-Actualization. While Disciplinary indicators include: Timeliness, Using office equipment properly, High responsibility, Compliance with office rules. While the indicators of Performance are Job Quantity, Job Quality, Independence, Initiative, Adaptability, and Cooperation. If the three independent variables are increasing, the dependent variable will increase. 
This validity testing study was carried out with the help of a computer using the SPSS for Windows version 20. In this study the validity testing was only carried out on 70 respondents. using explanatory research method with quantitative approach. The concepts in this study are three namely, education, motivation and discipline on performance with the independent variables of Education (X1), Motivation (X2), Discipline (X3) and Performance dependent of variables (Y). Data collection techniques through questionnaires, and documentation. Analysis of the data used is the statistical analysis of product moment and partial correlation data, multiple linear regression and coefficient of determination, partial test $\mathrm{t}$ and simultaneous test $\mathrm{F}$.

Before conducting data analysis, the research instrument must be tested for reliability and validity. This is done so whether the measuring instrument used is reliable and appropriate or not. Therefore, the validity and reliability tests are first performed.

\subsection{Research design}

This research is based on the indigenous psychology approach, which is research based on the understanding of humans in the local context (Indigenous) [22] so that the results of the research obtained are truly pure understanding of Indonesian people and can be applied according to the Indonesian cultural context.

\subsection{Sample}

This research was conducted in the Special Region of Yogyakarta. The characteristics of the research subject are the wife who identifies herself as Javanese, having children under 12 years of age who live with her husband, and work as professionals.

\subsection{Tool}

The research data was collected through a survey method using a work-family conflict scale, a husband support scale, a communal sharing social relationship scale, and a social equality matching scale given to 296 research subjects.

\subsection{Data Analysis}

The research data analysis used was a test measurement model at once against 3 constructs using path analysis.

\section{Results and Discussion}

Product Moment and Partial Correlation Test Results The magnitude of the correlation coefficient between the independent variables $(\mathrm{X} 1, \mathrm{X} 2, \mathrm{X} 3)$ with the dependent variable $(\mathrm{Y})$ in the calculation of product moment and partial correlations are not too much different. When tested with product moment, where testing the relationship of each independent variable $(\mathrm{X} 1, \mathrm{X} 2, \mathrm{X} 3)$ with the dependent variable $(\mathrm{Y})$ without controlling the other independent variables produce coefficient values (X1) 0.852 , (X2) 0.854 , (X3) 0.893 with a significance level of $5 \%$. While testing the partial correlation of each independent variable (X1, X2 and X3) with the dependent variable (Y) by controlling other independent variables that are considered influential produce a coefficient value.

Education variable data is obtained based on the results of measurements using a questionnaire that has a minimum score $=61$ and a maximum $=91$. The mean score is 84.67 , 
the median is 86 , and the mode is 80 . The range of scores is 30 and the standard deviation is 4.97. Motivation Variable (X2) Disciplinary data is obtained based on the results of measurements using a questionnaire that has a minimum score $=61$ and a maximum $=91$. A mean score of 84.63 , a median of 86 , and mode 80 . The range of scores is 30 and the standard deviation is 4.97. Disciplinary Variable (X3) Data Discipline is obtained based on the results of measurements using a questionnaire that has a minimum score $=61$ and a maximum $=91$. The mean score is 84.21 , the median is 86 , and the mode is 80 . The range of scores is 30 and the standard deviation is 4.97 .

Performance data is obtained based on the results of measurements using a questionnaire that has a minimum score $=62$ and a maximum $=98$. The mean score is 88.37 , the median is 89 and the mode is 88 . The range of scores is 36 and the standard deviation is 5.45 . The statistical results of the multiple linear regression test and the coefficient of determination test can be seen in table 1 below: The regression equation that can be formed from the influence of the variables Education, Motivation and Discipline together on the Performance variable is as follows:

$$
\begin{aligned}
& \mathrm{Y}=12,694+0,751 \mathrm{X} 1+0,591 \mathrm{X} 2+0,463 \mathrm{X} 3 \\
& \mathrm{Y}=\text { Performance } \\
& \mathrm{X} 1=\text { Education } \\
& \mathrm{X} 2=\text { Motivation } \\
& \mathrm{X} 3=\text { Discipline }
\end{aligned}
$$

Simultaneous test testing (F test) and partial test (t test) is done by comparing the significance value of $F$ with the level of significance $(\alpha)$ with a value of $\alpha=0.05$. If the significance of $\mathrm{F} \leq 0.05$, then $\mathrm{H} 0$ is rejected and $\mathrm{Ha}$ is accepted. Vice versa, if the significance of $\mathrm{F}>0.05$, then $\mathrm{H} 0$ is accepted and $\mathrm{Ha}$ is rejected. The results of partial testing ( $\mathrm{t}$ test) and simultaneous ( $\mathrm{F}$ test), it is known that the variables $\mathrm{X} 1, \mathrm{X} 2$ and $\mathrm{X} 3$ together have a significant effect on $\mathrm{Y}$ with a significance value below 0.05 and individually education has

\begin{tabular}{|c|c|c|c|}
\hline Variables & $\begin{array}{c}\text { t Count by } \\
\text { using } \mathrm{t} \text { table }\end{array}$ & $\begin{array}{c}\text { Significant by } \\
\text { Using } 0,05 \\
\end{array}$ & Conclusion \\
\hline $\begin{array}{l}\text { Education } \\
\text { (X1) }\end{array}$ & $4.547>1,995$ & $0,000<0.05$ & $\begin{array}{c}\text { Ho refused and } \\
\text { Ha accepted }\end{array}$ \\
\hline $\begin{array}{l}\text { Motivation } \\
\quad(\mathrm{X} 2)\end{array}$ & $.462>1,995$ & $0,000<0.05$ & $\begin{array}{c}\text { Ho refused and } \\
\text { Ha accepted }\end{array}$ \\
\hline $\begin{array}{l}\text { Discipline } \\
\text { (X3) }\end{array}$ & $.528>1,995$ & $0,000<0.05$ & $\begin{array}{c}\text { Ho refused and } \\
\text { Ha accepted }\end{array}$ \\
\hline $\begin{array}{l}\text { Performance } \\
(\mathrm{Y})\end{array}$ & $1.811>1,995$ & $0,000<0.05$ & $\begin{array}{c}\text { Ho refused and } \\
\text { Ha accepted }\end{array}$ \\
\hline \multirow{2}{*}{ Model } & \multirow{2}{*}{ t } & \multirow{2}{*}{ Zero-order } & relations \\
\hline & & & Partial \\
\hline
\end{tabular}
a significant influence significant with a significance value below 0.05 while to prove the effect of Education and Discipline variables have a significant effect together on Performance, the F-Test at the level of significant $(\alpha)=0.05$ is used.

Table 2. F Test 


\begin{tabular}{ccccccc}
\hline 1 & (Constant) & 6,343 &, 000 & & & \\
& x1 & 6,792 &, 000 &, 636 &, 636 &, 636 \\
2 & (Constant) & 6,081 &, 000 & & & \\
& x2 & 5,604 &, 000 &, 562 &, 562 &, 562 \\
3 & $($ Constant $)$ & 6,787 &, 000 & & & \\
& x3 & 4,963 &, 000 &, 516 &, 516 &, 516 \\
\hline
\end{tabular}

To determine the predicted change in the value of the dependent variable $(\mathrm{Y})$ caused by changes in the value of the independent variable $\left(\mathrm{X}_{1}\right),\left(\mathrm{X}_{2}\right)$ and $\left(\mathrm{X}_{3}\right)$, multiple linear regression analysis is used. In conducting this analysis using equations or multiple linear models, namely:

$$
Y=\beta 0+\beta 1 X_{1}++\beta 2 X_{2}+\beta 3 X_{3}
$$

To find out the value of $\beta$ o $\beta 1 \beta 2 \beta 3$, the results of regression of the independent variables to the dependent variable are used, namely Table 4.10 above. Based on the table, the values of $\beta$ o $39,030, \beta 1$ are equal to $544, \beta 2$ equal to $506, \beta 3$ equal to 436 . By obtaining the value of $\beta$ o $\beta 1 \beta 2 \beta 3$ for the independent variables $X_{1}, X_{2}, X_{3}$ then the equation or linear model can be made as follows:

$$
\mathrm{Y}=544+506+436
$$

The regression coefficient for the variable $\mathrm{X}_{1}(\beta 1)$ of 544 explains that the Education variable $\left(\mathrm{X}_{1}\right)$ will increase the value of the Performance variable $(\mathrm{Y})$ by $5.44 \%$ for each addition that occurs in Education. Likewise, with Variable $\mathrm{X}_{2}$, the Regression Coefficient ( $\beta 2$ ) is $5.06 \%$ times for each addition that occurs in the Motivation variable. Likewise, the $\mathrm{X}_{3}$ Variable Regression Coefficient ( $\beta 3$ ) is $4.36 \%$ times for each addition that occurs in the Discipline variable.

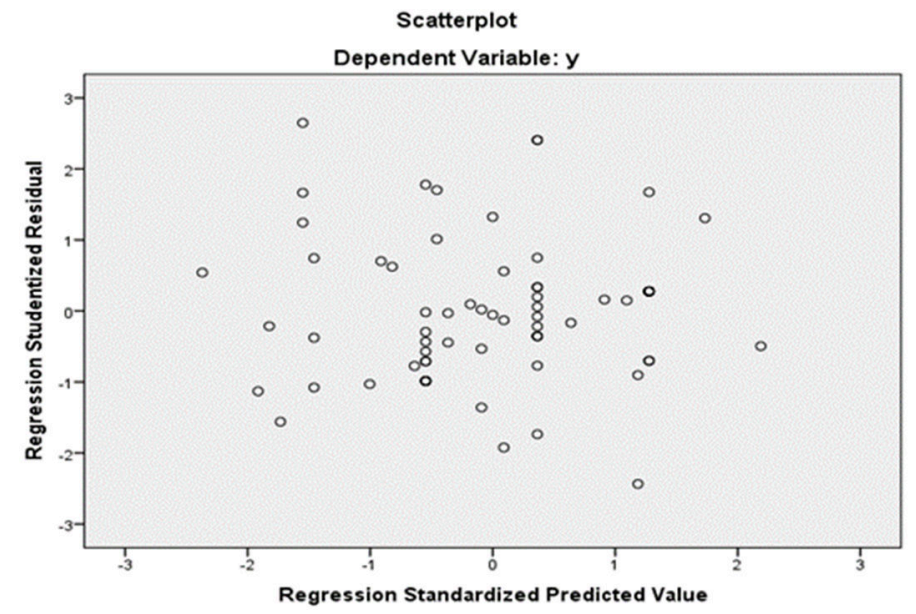

The curve of the estimation model between education $\left(\mathrm{X}_{1}\right)$, motivation $\left(\mathrm{X}_{2}\right)$, Discipline $\left(\mathrm{X}_{3}\right)$ against performance $(\mathrm{Y})$, appears to spread points and does not form a particular 
pattern. Thus, it can be said that the data shows a very influential heterogeneity of performance $(\mathrm{Y})$ based on variable input free. In this study used test $\mathrm{T}$, F Test, multiple linear regression analysis, correlation analysis and determination analysis to test the hypotheses that have been mentioned in the previous chapter. For hypotheses 1, 2, 3 (H1), (H2), (H3) used T tests while for hypotheses 3 (H3) used F tests, multiple linear regression analyses, correlation analysis and analysis of determinations.

To find out if the inter-variable relationship between XI, X2, and X3 against the dependent $\mathrm{Y}$ variable is simultaneously significant or not then the $\mathrm{F}$ test is performed. From the calculation result by using SPSS program obtained test-F calculation result at level of significant $(\alpha)=0.05$

Table 3. F Test

\begin{tabular}{|c|c|c|c|}
\hline Model & & $\mathrm{F}$ & Sig. \\
\hline \multirow[t]{3}{*}{1} & Regression & 14.245 & $.000^{\mathrm{a}}$ \\
\hline & Residual & & \\
\hline & Total & & \\
\hline
\end{tabular}

According to the above table known great Fcount $=14.245$ is greater than Ftabel $=2.409$, because Fcount $>$ ftable then Ho is rejected. While the F test is performed by looking at its significance probability value resulting in a probability value of $=0.000<\alpha=0.05$ then Ho is rejected, which means the education variable (X1), motivation (X2) and Discipline (X3) are significantly influential together towards performance $(\mathrm{Y})$.

So according to what is hypothesized that "there is a positive influence of education variable (X1), motivation (X2) and Discipline (X3) together against the performance variable $(\mathrm{Y})$ ", then for the medical hypothesis it proved according to the above table known great Fcount $=14.245$ is greater than Ftabel $=2.409$, because Fcount $>$ ftable then Ho is rejected. While the $\mathrm{F}$ test is performed by looking at its significance probability value resulting in a probability value of $=0.000<\alpha=0.05$ then Ho is rejected, which means the education variable (X1), motivation (X2) and Discipline (X3) are significantly influential together towards performance $(\mathrm{Y})$.

So according to what is hypothesized that "there is a positive influence of education variable (X1), motivation (X2) and Discipline (X3) together against the performance variable $(\mathrm{Y}) "$, then for the medical hypothesis it proved

Table 4. Multiple Regression Analysis

\begin{tabular}{|c|c|c|c|c|c|c|c|}
\hline & \multirow{2}{*}{ Model } & \multicolumn{3}{|l|}{ Standardized } & \multicolumn{3}{|c|}{ Correlations } \\
\hline & & Beta & & & Zero-order & Partial & Part \\
\hline \multirow{2}{*}{1} & (Constant) & & 6,343 &, 000 & & & \\
\hline & $\mathrm{X}_{1}$ & ,636 & 6,792 &, 000 & ,636 & ,636 & ,636 \\
\hline \multirow{2}{*}{2} & (Constant) & & 6,081 &, 000 & & & \\
\hline & $\mathrm{X}_{2}$ & ,562 & 5,604 &, 000 & ,562 & ,562 & ,562 \\
\hline
\end{tabular}




\begin{tabular}{|c|c|c|c|c|c|c|c|}
\hline \multirow{2}{*}{3} & (Constant) & & 6,787 &, 000 & & & \\
\hline & $X_{3}$ & ,516 & 4,963 & ,000 & ,516 &, 516 &, 516 \\
\hline
\end{tabular}

To find out which dimensions of the most dominant and large independent variables affect the dimensions of the dependent variable then the used matrix correlation between dimensions. That way the organization has an overview of deciding what concrete steps to take to make the performance produced by the Education military more than ever. This is very important because if the dimensions of the variable increase it increases the dimensions of each of its variables. As for the correlation that occurs between dimensions can be presented in the table below:

Table 5. Correlation between dimensions

\begin{tabular}{|c|c|c|c|c|c|}
\hline \multicolumn{6}{|c|}{ Correlations } \\
\hline & & $\mathrm{X} 1$ & $\mathrm{X} 2$ & $\mathrm{X} 3$ & $\mathrm{Y}$ \\
\hline \multirow[t]{4}{*}{ Education } & Pearson & 1 & $.334^{* *}$ & $.450^{* *}$ & $.241^{*}$ \\
\hline & Correlation & & & & \\
\hline & Sig. (2-tailed) & & .005 & .000 & .045 \\
\hline & $\mathrm{N}$ & 70 & 70 & 70 & 70 \\
\hline \multirow[t]{3}{*}{ Motivation } & Pearson & $.334^{* *}$ & 1 & $.487^{* *}$ & $.390^{* *}$ \\
\hline & Sig. (2-tailed) & .005 & & .000 & .001 \\
\hline & $\mathrm{N}$ & 70 & 70 & 70 & 70 \\
\hline \multirow[t]{3}{*}{ Discipline } & $\begin{array}{l}\text { Pearson } \\
\text { Correlation }\end{array}$ & $.450^{* *}$ & $.487^{* *}$ & 1 & $.390^{* *}$ \\
\hline & Sig. (2-tailed) & .000 & .000 & & .001 \\
\hline & $\mathrm{N}$ & 70 & 70 & 70 & 70 \\
\hline \multirow[t]{3}{*}{ Performance } & $\begin{array}{l}\text { Pearson } \\
\text { Correlation }\end{array}$ & $.241^{*}$ & $.390^{* *}$ & $.390^{* *}$ & 1 \\
\hline & Sig. (2-tailed) & .045 & .001 & .001 & \\
\hline & $\mathrm{N}$ & 70 & 70 & 70 & 70 \\
\hline
\end{tabular}

**. Correlation is significant at the 0.01 level (2-tailed).

*. Correlation is significant at the 0.05 level (2-tailed).

Based on the data listed in the table above, it can be concluded as follows: It can be seen that the significance value in the education variable (X1) is 0.00 , in the motivational variable (X2) is 0.00 and the Discipline (X3) is the 0.00 which in the formula test correlation when the significance of $<0.05$ then correlates whereas when the significance value $>0.05$ is not correlated Thus, it can be deduced there is a correlation to performance (Y). At the relationship degree guidelines on the Pearson value Correlation used the following interpretation guidelines: $0.00-0.20$ : No correlation, $0.21-0.40$ : Weak correlation, $0.41-0.60$ : Moderate correlation, 0.61-0.80: Very strong correlation, 0.81-1.00: Perfect Correlation.

Based on the interpretation above then the Pearson Correlation education value (X1) is a 0.636 strong correlation, motivation (X2) is a 0.562 medium correlation, Discipline (X3) 0.516 medium correlation to Performance $(\mathrm{Y})$ 1.00. So that the correlation that is concluded 
is the perfect interrelated relationship between each independent variable against the Dependent variables.

Multicollinearity in linear regression models can be examined using the Variance inflation factor (VIF) of each variable. Tolerance measures the variability of the selected free variables that are not described by other variables where the value is Tolerance $<0.10$ or equal to the VIF value of $>10$. The multicollinearity test results can be described according to the following table.

Table 6. Multicollinearity Test

\begin{tabular}{llll}
\hline \multirow{2}{*}{ Model } & \multicolumn{2}{l}{$\begin{array}{l}\text { Collinearity } \\
\text { Tolerance }\end{array}$} & $\begin{array}{c}\text { Statistics } \\
\text { VIF }\end{array}$ \\
\hline 1 & (Constant) & & \\
& Education & .780 & $\mathbf{1 . 2 8 2}$ \\
& Motivation & .746 & $\mathbf{1 . 3 4 0}$ \\
& Discipline & .670 & $\mathbf{1 . 4 9 2}$ \\
\hline
\end{tabular}

The statistical test used is the glacier test for accurate results. From the results of the test will be decided, if the significance number $>0.05$ at the level of confidence $95 \%$, then there is no heteroscedastic (Ghozali, 2013:143). The results of heteroscedastic testing can be described according to the following table:

Table 7. Coefficients ${ }^{\mathrm{a}}$

\begin{tabular}{|c|c|c|c|c|c|c|c|}
\hline \multirow[t]{5}{*}{ Model } & \multicolumn{5}{|c|}{ Std } & \multirow{3}{*}{\multicolumn{2}{|c|}{$\begin{array}{l}\text { Collinearity } \\
\text { Statistics }\end{array}$}} \\
\hline & \multirow{2}{*}{\multicolumn{2}{|c|}{$\begin{array}{l}\text { Unstandardized } \\
\text { Coefficients }\end{array}$}} & \multirow{2}{*}{\multicolumn{3}{|c|}{$\begin{array}{l}\text { Coeffici } \\
\text { ents }\end{array}$}} & & \\
\hline & & & & & & & \\
\hline & & Std. & & & \multirow[b]{2}{*}{ Sig. } & \multirow[b]{2}{*}{ Tolerance } & \multirow[b]{2}{*}{ VIF } \\
\hline & $\mathrm{B}$ & Error & Beta & $\mathrm{t}$ & & & \\
\hline $1 \quad$ (Constant) & 5.280 & 5.751 & & .918 & .362 & & \\
\hline Education & .051 & .061 & .115 & .835 & .407 & .780 & 1.282 \\
\hline Motivation & -.069 & .063 & -.153 & -1.085 & .282 & .746 & 1.340 \\
\hline Discipline & -.005 & .060 & -.013 & -.090 & .928 & .670 & 1.492 \\
\hline
\end{tabular}

a. Dependent Variable: RES2

b. Data: Result of Data

On the education variable, the correlation between the dimensions of performance with Pearson Correlation the highest value is 0.581 and the correlation is relatively strong. While the lowest correlation between the dimension of subordinate ability to control the dimension of discipline Pearson Correlation value 0.269. and the correlation is moderate. In Motivation the correlation between the dimension of aggressiveness and the dimension of task implementation has the highest correlation value with the Pearson Correlation value of 0.570 and the correlation is relatively strong. While the lowest correlation value is 0.270 the correlation between the performance. In the discipline variable, the correlation between work on time have lowest correlation value 0.384 while the highest is loyalty 0.627 . 


\section{Conclusions}

Simultaneously education, motivation and discipline are having contribute significantly to employee performance together. While the remaining is determined by other variables. Based on the findings of this study it can be concluded that annual education for personnel will give more contribute to the career in the future. The motivation also has significant effect of work performance, based on the results of data analysis through of the respondent statement. This study aims to examine the effect of education, motivation and discipline on the performance of military personnel Education Services. Education has a positive and significant effect on performance military personnel at Naval Education Services. That the highest score is dimension Skill totally 0.581. Motivation has a positive and significant effect on the performance military personnel at Naval Education Services. That the highest score is dimension Need pleasure and safety totally is 0.570 . Discipline has a positive and significant effect on the performance military personnel at Naval Education Services. That the highest score is dimension loyalty totally is 0.627

Some Suggestions that researcher made include: Naval Education Service is verry important to strengthen education in their institution. Naval Education Service is verry important to strengthen motivation in their institution. Naval Education Service is verry important to strengthen discipline in their institution. Therefore, for further research, it is expected to examine more deeply others variables that may have a significant influence on the performance personnel. Research on 4.0 era should be done more, both related to the problems of education, motivation and discipline considering the millennial generation is workforce that will rule the workforce in the future.

\section{References}

[1] A. A. A. P. Mangkunegara, Manajemen Sumber Daya Manusia Perusahaan. 2003.

[2] D. J. Priansa, "Manajemen Kinerja Kepegawaian dalam Pengelolaan SDM Perusahaan," in Cetakan ke-1, 2017.

[3] P. J. Donni, Perilaku Konsumen Dalam Persaingan Kontemporer. 2017.

[4] K. A. Roni, A. Moein, and N. I. Effendi, "Determination of Work Motivation and its Implication on Employee Performance Secretariat of Kpu Se-Province Jambi," Int. Rev. Manag. Mark., 2018.

[5] M. Kadarisman, "Manajemen Pengembangan Sumber Daya Manusia," Rajawali Press. Jakarta. 2012.

[6] M. Inuwa, "Job Satisfaction and Employee Performance: An Empirical Approach," Millenn. Univ. J., 2016.

[7] E. T. K. Demann, P. S. Stein, C. Levitt, and K. E. Shelton, "Employee Relations," Dental Clinics of North America. 2008, doi: 10.1016/j.cden.2008.02.005.

[8] K. Umar, "Employee engagement organizational performance," adademia.edu, 2014.

[9] D. Setyadi and A. Sriekaningsih, "The Effect Of Competence And Motivation And Cultural Organization Towards Organizational Commitment And Performance On State University Lecturers In East Kalimantan Indonesia,” Eur. J. Bus. Manag., 2015.

[10] A. Hameed, M. Ramzan, M. Hafiz, M. Kashif Zubair, G. Ali, and M. Arslan, "Impact of compensation on employee performance," Int. J. Bus. Soc. Sci., 2014.

[11] W. H. Reid, "Human resources," Handbook of Mental Health Administration and Management. 2013, doi: 10.4324/9781315777221-3.

[12] M. Manullang, Dasar-Dasar Manajemen (Cetakan ke-21). 2009. 
[13] C.-R. Giroux, "The Motivation to work, by F. Herzberg, B. Mausner and B.-C. Snyderman, John Wiley \& Sons, New York, John Wiley \& Sons, 1959.," Relations Ind., 2017, doi: 10.7202/1022040ar.

[14] Sedarmayanti, "Reformasi Birokrasi dan Manajemen Pegawai Negeri Sipil," in Manajemen Sumber Daya Manusia, 2011.

[15] F. N. Al-Madi, H. Assal, F. Shrafat, and D. Zeglat, "The Impact of Employee Motivation on Organizational Commitment,” Eur. J. Bus. Manag., 2017.

[16] S. J. O'Connor, N. Borkowski, and R. Kemp, "Employee motivation," in Handbook of Healthcare Management, 2015.

[17] A. B. Saluy, T. Musanti, and B. Mulyana, "PENGARUH PELATIHAN, MOTIVASI KERJA DAN KOMPETENSI TERHADAP KINERJA PERSONEL DI MAKOSEK HANUDNAS I.,”J. Manag. Bus. Rev., 2019, doi: 10.34149/jmbr.v16i1.151.

[18] Z. Hamid, M. Muzamil, and S. A. Shah, "Strategic human resource management," in Handbook of Research on Positive Organizational Behavior for Improved Workplace Performance, 2019.

[19] A. P. M. dan A. Waris, "Effect of Training, Competence and Discipline on Employee Performance in Company (Case Study in PT. Asuransi Bangun Askrida)," Procedia - Soc. Behav. Sci., 2015, doi: 10.1016/j.sbspro.2015.11.165.

[20] A. B. Saluy and Y. Treshia, "Pengaruh Motivasi Kerja, Disiplin Kerja dan Kompensasi Terhadap Kinerja Karyawan (Studi Kasus di Perusahaan PT IE),” J. Univ. Mercu Buana, 2018 . 